\title{
Increasing labor productivity as the major line of agricultural industry development
}

\author{
Elena A. Smirnova* and Marina $V$. Postnova \\ Ulyanovsk State Agrarian University named after P.A. Stolypin, 432017 Ulyanovsk, Russia
}

\begin{abstract}
The improvement of the agricultural sector efficiency, a shift to innovative development approaches to increase the competitiveness of domestic agriculture in modern conditions is possible only if labor productivity increases. This task is more relevant today than ever, since the main factor of production - labor (labor resources) has a steady downward trend. The study has shown that in the agricultural sector of the region there is an increase of labor productivity both by value and volume. The application of deterministic factor analysis has revealed that in the dynamics both factors (number of employees and cost of production) had a positive impact on increasing labor productivity, but the increase in production volumes in the industry had a more noticeable effect (the value of the factor varied from 57.7 to $69.7 \%$ ). However due regard must be paid to the fact that agricultural production is subject to fluctuations and the decrease in the number of workers in the industry is sustainable. The positive impact and the main factor in the growth of annual labor productivity is an increase in the average hourly output of workers due to an increase in the yield and technical re-equipment, and this should be noted as a strategically important direction for the development of the industry. The normalization of employment also acts as a factor in further increasing labor productivity.
\end{abstract}

\section{Introduction}

The growth of production in any sector of the national economy can be achieved by increasing the volume of resources or by using them more efficiently, even if they are reduced. This task is especially relevant for the agricultural industry. Of all the resources involved in the production process, the most important is workforce. Due to the sector reforms, objective scientific and technical process, modernization of production, the population of rural settlements and labor resources of agricultural enterprises is constantly decreasing $[1,2]$. Analysis of labor resources in the Ulyanovsk region has shown the following results.

\section{Results and discussion}

By the beginning of 2018 the population of the Ulyanovsk region amounted to 1246.6 thousand people, living in rural areas -307.9 thousand people or $24.7 \%$. This amounts to $0.8 \%$ of the country's population and $4.2 \%$ of the population of the Volga Federal District. In terms of population, Ulyanovsk region ranks the $11^{\text {th }}$ place in the Volga Federal District. Over the past five years (since 2014), the population of the Ulyanovsk region decreased by 21 thousand people or $1.7 \%$. Over the same period, the rural population decreased by 18.9 thousand people or $5.8 \% .90 \%$ reduction in the region's population is due to a decrease in rural residents.
The percentage of the rural population also tends to decrease from 25.5 to $24.7 \%$. A negative trend in the structure of the rural population can be observed as follows: the percentage of the working-age population is reducing from 55.3 to $51.7 \%$, and the percentage of the population older than working-age is increasing from 29.3 to $32.8 \%$. The decline in the working-age population directly affects the number of people employed in the main type of economic activity, "Agriculture, Hunting, and Forestry". Employees in the agricultural sector include people who worked in agricultural organizations and in agricultural service organizations, in peasant farms or husbandry farms, as well as self-employed without forming a legal entity and employed in agricultural farms for selling products.

The number of people employed in agriculture in the Ulyanovsk region is 49.3 thousand people that make $8.49 \%$ of the economy. In relation to 2014 , the number of people employed in the agricultural sector decreased by 20.6 thousand people or $29.5 \%$, it is necessary to note a slowdown of the decline in employment in recent years.

The level of the rural population employment is an indicator of the well-being of the rural areas social development. An unfavorable demographic situation, a reduction in the working-age population, especially young people, complicates the situation with labor force in rural areas. The accumulated production and social problems cause high attrition rate of agricultural workers. As a result, the agricultural sector lacks

\footnotetext{
Corresponding author: ya.cmirnov2012@yandex.ru
} 
professional staff, which leads to a slowdown in the economic development of rural territories [3, 4].

A feature of agricultural development is the production in farms of different types and hence the distribution of labor resources. Agricultural enterprises of the region currently employ $16.3 \%$ of the labor resources of the industry, peasant farms account for $3.2 \%$, and the majority of the employed $80.5 \%$ falls on farms. At the same time, the main agricultural production is concentrated in the agricultural enterprises of the region $-48 \%$, therefore this area requires a more thorough analysis.

The problem is labor supply for agricultural enterprises, where there is a clear tendency of staff reduction. The number of agricultural employees in the Ulyanovsk Region in 2018 amounted to 7,526 people (Fig. 1), over five years, labor resources decreased by 2,738 people (by $26.7 \%$ ), and during the reporting year by 517 people (by $6.4 \%$ ).

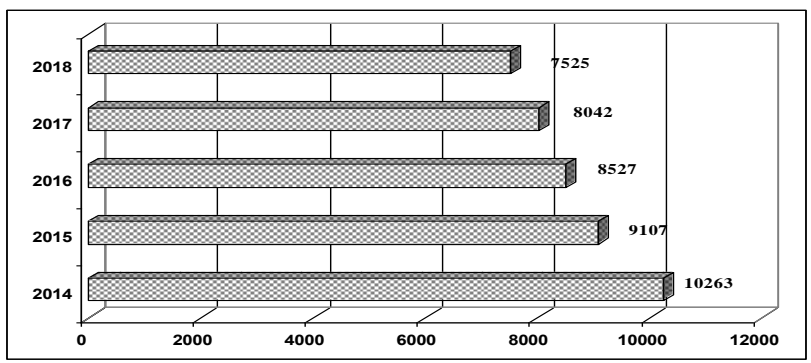

Fig. 1. Dynamics of the average annual number of employees of agricultural enterprises of Ulyanovsk region

The main proportion of labor force $21.5 \%$ is tractor drivers - machine drivers, $9.6 \%$ of workers are employed in the livestock sector and $2.8 \%$ in pig husbandry (Fig. 2). Managers and specialists hold a high proportion $-22.7 \%$. Significant changes occurred in the plant-raising compared to 2014. The proportion of plant workers increased by 4.8 percentage points (pp), pig and sheep workers by 2 times, employees by $3 \mathrm{pp}$, but the proportion of machine milking operators and cattle workers decreased by $0.6 \mathrm{pp}$. The changes that have occurred are associated with a more intensive development of these industries and a slowdown in the development of the beef cattle breeding industry.
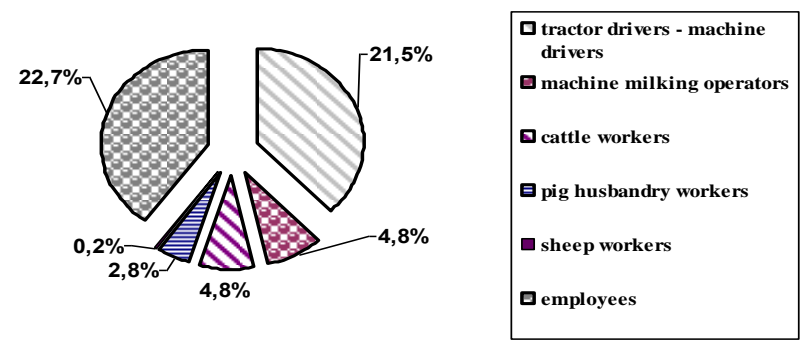

Fig. 2. Labor force structure of agricultural enterprises of Ulyanovsk region

In general, there was an outflow of labor force from public farms to private farm holdings during the years of reforms. In 2018, the number of workers in peasant farms in the region was only 1,681 people, including the head of the farm - 455 people, family members not registered as members of the farm - 272 people, permanent employees - 545 people; temporary and seasonal workers - 390 people.

The number of employees of self-employed entrepreneurs was only 1335 people, including entrepreneurs -303 people, helping family members of self-employed entrepreneurs - 323 people, employees working on a regular basis - 335 people, temporary and seasonal workers - 361 people.

Unlike agricultural enterprises, the number of workers in peasant farm enterprises in dynamics increased from 1274 people in 2012 to 1681 people during the reporting year, or by $32 \%$, but their proportion in the structure of employees is very low.

The reduction of labor resources in the industry is the result of scientific and technological progress, the application of new technologies, mechanization and automation of production [5]. With a decrease in the labor resources of the industry, the task of increasing labor productivity is becoming especially relevant. The improvement of competitiveness in the agricultural sector, manufactured products in modern conditions has to be achieved due to increased labor productivity [6-8].

The growth of labor productivity in agriculture, or reduction in labor costs per unit of output, remains important indicators and conditions for the stable development of the agricultural economy. Due to poor demographic indicators, lack of labor and financial resources, investments, increasing labor productivity is one of the priority tasks of managing agricultural production. The significance of this task is also enhanced by the fact that the level of labor productivity in agriculture in the Russian Federation lags significantly behind developed countries.

The analysis of labor productivity over the past period has been carried out to identify trends in the development of processes of changing labor productivity indicators, as well as to analyze the existing situation and compare with industry values $[9,10]$. The agricultural sector of the Ulyanovsk region demonstrates a rather high growth rate of labor productivity.

In recent years, the index was 105 (103.9 in the Russian Federation). The growth of labor productivity index is mainly provided by agricultural enterprises (114.8) and farms (117.2). The better indicator of assessing labor efficiency is labor productivity, which was calculated taking into account the characteristics of agricultural production (Fig. 3).

The dynamics of labor productivity in agricultural enterprises of Ulyanovsk region has a positive trend. In relation to 2014, the annual and hourly output increased by 2.1 times, moreover, it has increased more significantly during the reporting period - by 26.9 and by $34.8 \%$, respectively. A more objective assessment of labor productivity dynamics is natural indicators in the production of certain types of crop and livestock products (Table 1 ).

The main types of products per 1 worker employed in agricultural sector has increased: cattle meat from 4.4 to 5.4 c.or by $22.7 \%$, milk - from 79.4 to 105.5 c. or 
$32.9 \%$, grain - from 598.5 to 1461.4 c. or by 2.4 times, potatoes - from 10.6 to $17.8 \mathrm{c}$. or by $67.9 \%$, sunflower from 123.2 to $187.2 \mathrm{c}$. or by $51.9 \%$ [11].

The most significant increase in production per 1 agricultural worker was achieved in the production of grain and sunflower. A decrease in productivity is observed in the production of rapeseed and sugar beet.

The presented data show a tendency to increase labor productivity in agricultural enterprises of the region, due to state policy related to import substitution of products and technical re-equipment of the industry. In order to carry out a more detailed study of the dependence of factors influencing on labor productivity, methods of deterministic factor analysis were applied [12, 13] (Table 2).

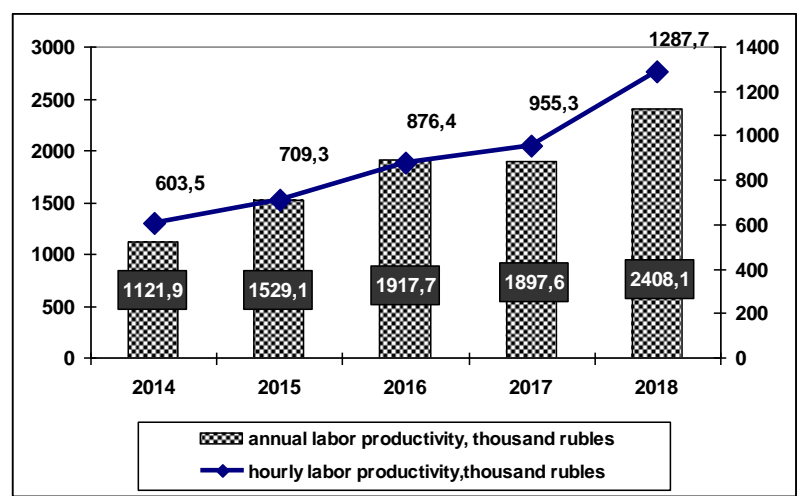

Fig. 3. Dynamics of labor productivity in agricultural enterprises of Ulyanovsk region

Table 1. Production per 1 worker employed in agricultural production (center)

\begin{tabular}{|c|c|c|c|c|c|c|c|}
\hline $\begin{array}{c}\text { Types of } \\
\text { products }\end{array}$ & 2013 & 2014 & 2015 & 2016 & 2017 & \multicolumn{2}{|c|}{$2017 \%$ to } \\
\hline Grain & 598.5 & 789.5 & 765.7 & 1085.7 & 1461.4 & 244.2 & 134.6 \\
\hline Sunflower & 123.2 & 135.1 & 150.7 & 250.2 & 187.2 & 151.9 & 74.8 \\
\hline Sugar beet & 250.3 & 209.7 & 295.2 & 371.2 & 286.3 & 114.4 & 77.1 \\
\hline Rapeseed & 8.2 & 6.1 & 5.4 & 4.9 & 4.0 & 48.8 & 81.6 \\
\hline Potatoes & 10.6 & 11.8 & 17.9 & 18.6 & 17.8 & 167.9 & 95.7 \\
\hline Milk & 79.4 & 88.3 & 93.6 & 96.7 & 105.5 & 132.9 & 109.1 \\
\hline Cattle meat & 4.4 & 5.2 & 5.0 & 5.4 & 5.4 & 122.7 & 100.0 \\
\hline
\end{tabular}

Table 2. Main impact factors on the change in the annual labor productivity of workers in agricultural enterprises of Ulyanovsk region

\begin{tabular}{|c|c|c|c|c|c|}
\hline \multirow{2}{*}{$\begin{array}{c}\text { Indicators, } \\
\text { period }\end{array}$} & \multicolumn{5}{|c|}{ Change in annual labor productivity } \\
\cline { 2 - 6 } & \multirow{2}{*}{$\begin{array}{c}\text { Total, } \\
\text { thousand roubles }\end{array}$} & \multicolumn{4}{|c|}{ including due to } \\
\cline { 3 - 6 } & & \multicolumn{2}{|c|}{ number of employees } & \multicolumn{2}{c|}{ cost of products } \\
\cline { 3 - 6 } & & thousand roubles & $\%$ & thousand roubles & $\%$ \\
\hline 2014 to 2013 & 262.2 & 172.2 & 42.3 & 235.0 & 57.4 \\
\hline 2015 to 2014 & 407.2 & 122.1 & 31.4 & 266.5 & 67.7 \\
\hline 2016 to 2015 & 388.6 & 107.9 & - & -128.0 & - \\
\hline 2017 to 2016 & -20.1 & 154.6 & 30.3 & 355.9 & 69.7 \\
\hline 2018 to 2017 & 510.5 & 771.4 & 49.8 & 777.0 & 50.2 \\
\hline 2018 to 2013 & 1548.4 & 644 & 50.1 & 642.2 & 49.9 \\
\hline 2018 to 2014 & 1286.2 & & & & \\
\hline
\end{tabular}

The efficiency of labor force in the region is subject to certain fluctuations, the growth rate of labor productivity is characterized by significant variation. Fluctuations can be traced both in the rate of production growth and in the rate of employees number change.

As a result of factor analysis, it has been found that both factors (number of employees and cost of production) had a positive impact on the increase in labor productivity (with the exception of 2017). Due to a reduction in the number of employees, labor productivity in 2018 compared to 2017 increased by 154.6 thousand rubles owing to an increase in agricultural production by 355.9 thousand rubles.

The main growth factor is the increase in production; the factor contribution was $69.7 \%$. The exception was 2017, as a result of the combined impacts, a decrease in labor productivity amounted to 20.1 thousand rubles, which was associated only with a decrease in production volume. As a result, the production decreased by 128 thousand rubles per person. A reduction in the number of employees increased productivity by 107.9 thousand rubles.

As a positive trend, it should be noted a more significant contribution to the growth of labor productivity, an increase in the cost of production for all analyzed years (the value of the factor varied from 57.7 to $69.7 \%$ ) and the role of this factor is growing. For the analyzed five-year period, the impact of factors is almost the same (contribution is 50.2 and $49.8 \%$ ), since in 2017 only the decrease in the number of employees affected the growth of labor productivity.

This trend suggests that agricultural production is subject to fluctuations and the decline in the number of workers in the industry is sustainable.

The impact of factors such as the number of days worked per one employee (annual employment), daily employment of an employee, average hourly output of 
an employee on the level of annual labor productivity was estimated applying the following models:

- increase in labor productivity due to the number of days worked by one employee per year ( $\Delta$ number of days worked by one employee $\times$ daily employment of an employee $\times$ average hourly output of an employee of a base year)

$2014=8.43$ days $\times 6.17$ hours $\times 0.37501$ thousand rubles $=23.75$ thousand rubles.

$2015=2.25$ days $\times 7.1$ hours $\times 0.60349$ thousand rubles $=9.64$ thousand rubles.

$2016=-5.61$ days $\times 7.34$ hours $\times 0.70933$ thousand rubles. $=-29.21$ thousand rubles.

$2017=-26.61$ days. $\times 7.31$ hours $\times 0.87643$ thousand rubles $=-169.63$ thousand rubles .

$2018=-19.5$ days $\times 7.41$ hours $\times 0.9553$ thousand rubles $=-138.04$ thousand rubles.

2018 to $2014=-49.27$ days $\times 7.41$ hours $\times 0.60349=-$ 220.33 thousand rubles.

- an increase in labor productivity due to the length of working hours ( $\Delta$ daily employment of an employee $\times$ number of days worked by one employee $x$ average hourly output of a base year)

$2014=-1.65$ hours $\times 301.47$ days $\times 0.37501$ thousand rubles. $=-186.54$ thousand rubles.

$2015=0.93$ hours $\times 303.72$ days $\times 0.60349$ thousand rubles $=169.32$ thousand rubles.
$2016=0.24$ hours $\times 298.11$ days. $\times 0.70933$ thousand rubles. $=50.75$ thousand rubles.

$2017=-0.03$ hours $\times 271.75$ days $\times 0.87643$ thousand rubles. $=-7.15$ thousand rubles.

$2018=0.105$ hours $\times 252.2$ days $\times 0.9553$ thousand rubles $=25.30$ thousand rubles.

2018 to $2014=1.24$ hours $\times 252.2$ days $\times 0.60349=$ 188.73 thousand rubles.

- increase in labor productivity due to the average hourly output of employees ( $\Delta$ average hourly output of an employee $\times$ number of days worked by one employee $\times$ daily employment of an employee)

$2014=0.22848$ thousand rubles $\times 301.47$ days $\times$ 6.17 hours $=424.99$ thousand rubles

$2015=0.10584$ thousand rubles $\times 303.72$ days $\times$ 7.1 hours $=228.23$ thousand rubles $2016=0.1671$ thousand rubles $\times 298.11$ days. $\times$ 7.34 hours $=367.06$ thousand rubles.

$2017=0.7887$ thousand rubles $\times 271.75$ days $\times$ 7.31 hours $=156.67$ thousand rubles $2018=0.33240$ thousand rubles $\times 252.2$ days. $\times$ 7.41 hours $=619.14$ thousand rubles.

2018 to $2014=0.68421$ thousand rubles $\times 252.2$ days $\times$ 7.41 hours $=1278.65$ thousand rubles.

The final values of impact factors on the level of annual labor productivity of workers of agricultural enterprises of the region are presented in table 3.

Table 3. Assessment of impact factors on the level of annual labor productivity of workers at agricultural enterprises of Ulyanovsk region

\begin{tabular}{|l|c|c|c|c|c|c|}
\hline \multicolumn{1}{|c|}{ Indicators } & 2014 & 2015 & 2016 & 2017 & 2018 & 2018 to 2014 \\
\hline $\begin{array}{l}\text { Change in annual labor productivity of 1 } \\
\text { employee to the previous year, thousand rubles }\end{array}$ & 262.2 & 407.2 & 388.6 & -20.1 & 510.5 & 1286.2 \\
\hline \multicolumn{7}{|l|}{ Change in labor productivity, thousand rubles: } \\
\hline - number of days worked by 1 employee & 23.75 & 9.64 & -29.21 & -169.63 & -138.04 & -220.33 \\
\hline - daytime employment & -186.54 & 169.32 & 50.75 & -7.15 & 25.30 & 188.73 \\
\hline - hourly average output & 424.99 & 228.23 & 367.06 & 156.67 & 619.14 & 1278.65 \\
\hline
\end{tabular}

\section{Conclusion}

Over the analyzed period (2014 to 2018), the increase in annual labor productivity is largely due to an increase in hourly output of workers, which grew by 684.21 rubles over this period and increased productivity by 1.3 million rubles. As a result of the increase in the daily employment of workers from 6.17 to 7.41 hours, the annual labor productivity increased by 188.73 thousand rubles. The negative impact caused a decrease in the annual employment of workers from 301.5 to 252.2 days, which reduced labor productivity by 220.33 thousand rubles.

Within the time period, the impact factors on labor productivity were different. The decrease in the number of days worked by one employee was in 2016-2018, especially in 2017 due to this factor, productivity decreased by 169.63 thousand rubles (this is the main factor in reducing of labor productivity in the reporting year).

It should be noted that the annual employment of workers in 2018 is lower than the normative working time fund; therefore this factor must be used to increase the level of labor productivity at agricultural enterprises of the region.

The negative impact of daily employment on labor productivity was noted in 2014 and 2017, but the strength of this impact is negligible in recent years. The increase in daily employment of workers cannot be offered to increase labor productivity, since daily employment at enterprises is higher than the standard value.

The main factor of the growth of annual labor productivity at agricultural enterprises of the region over all analyzed years is the increase in the average hourly output of workers - due to an increase in output and a decrease in the annual employment of workers, and this should noted as a strategically important direction for the development of the industry.

The agricultural sector of the region faces up to the challenge of increasing its competitiveness and the major line is the growth of labor productivity. The study of labor productivity of agricultural production is the basis for identifying the reserves of its growth, taking into account the regional characteristics of agricultural production. 
Understanding of the factors explaining differences in labor productivity is important for determining the directions of its increase and development of the agricultural sector.

\section{Acknowledgments}

The study was carried out with the financial support of the Russian Federal Property Fund and the Ulyanovsk Region in the framework of the scientific project No. $18-410-730018$

\section{References}

1. E. Tarasova, E. Smirnova, M. Postnova, Study of rural labor resources and employment in the agricultural sector of the Ulyanovsk region, Econ. of Agricult. of Russ., 10, 52-56 (2018)

2. A. Ivanov, I. Ilyina, Comprehensive assessment of labor productivity as a necessary condition for increasing the efficiency of its management, Bull. of the Kursk State Agricult. Acad., 4, 29-33 (2016)

3. E. Tarasova, E. Pogodina, The predicted tendencies of labor potential development in agrarian sector of the Ulyanovsk region, J. of Econ. and Entrepreneurship, 11.2(76-2) (2016)

4. E. Boltunova, A. Navasardyan, O. Khamzina, The state of the labor market in rural areas (on the example of the Ulyanovsk region), Econ., labor, managem. in agricult., 1(26), 47-49 (2016)

5. A. Nurullin, A. Subaeva, N. Aleksandrova, Performance as the main factor of expanded reproduction, IIOAB J., 10.S2, 12-16 (2019)
6. L Silayeva, A. Didyk, Labour productivity in agriculture, AIC: econ., managem., 10, 16 (2014)

7. Yu. Orshanskaya, Impact of labor productivity on the competitiveness of agricultural products in Russia in terms of accession to the EAEU, Econ., labor, managem. in agricult., 12(45), 138-141 (2018)

8. Ya. Galiullin, G. Ermakov, M. Simonova, Concept of labor efficiency, Russ. J. of Labor Econ., 4(3) (2017)

9. L.I. Khoruzhii, N. Yu. Triastsina, M.N. Dorofeeva, Analysis of labor productivity in the agricultural organizations of the Moscow region, Account. in agricult., 2, 57-65 (2018)

10. O.A. Stolyarova, Increase of labor productivity and efficiency of use of labor resources in agriculture of the Penza region, Niva Povolzhya, 1(46), 75-82 (2018)

11. E. Smirnova, M. Postnova, E. Tarasova, Assessment of the level of labor productivity in agricultural enterprises of the Ulyanovsk region, Bulletin of Kazan State Agrarian University, 13,3(50), 140-146 (2018)

12. V. Bogdanovsky, Factors and reserves of labor productivity growth in agriculture, Econ., labor, managem. in agricult., 9(42), 114-121 (2018)

13. A. Belokopytov, A. Cernovcy, Factor analysis of the performance of agricultural labor in the development of the region, Labour econ., 6(1), 285-294 (2019) 